Изъ клиники нервныхъ бользней Казанскаго Университета (Дир. проф Л. О. Даркшевичъ).

\title{
Спучай хронической прогрессивной хореи.
}

\author{
Ординатора В. Д ПАПУХИНА.
}

Больной Т., котораго имью честь представить Обществу ${ }^{1}$ ), страдаетъ той формой забольванія, которая по типической картинь можеть быть опрйделена, кақъ chorea chronica progressiva. Первымъ выдьвившимъ хроническую прогрессивную хорею, какъ отдвльную возологическую единиц, быль америкавскій вевропатологъ Huntington, въ честь потораго хровическая хорея долгее время носила названіе „Ниntington'овской хореи“, въ отличіе отъ chorea minor, описанной впервые Sydenham'омъ; посльддняя является болъе обыч-

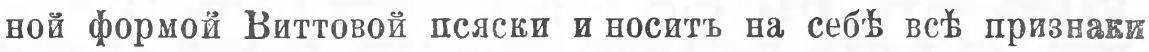
остраго ивфевціоннаго забольванія. Кагъ изв屯етно, Huntington держался взгляда, что хровическая прогрессивная хорея всегда является насльдственнымъ страдавіемъ. Но позднвйшія описанія уже не придають тавого исключительнаго значенія насльдсственвости. Hofmann усматриваетъ главный при-

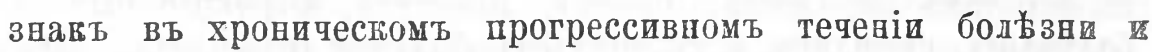
шреддагаеть замънить назвавіе „chorea hereditaria" терминомъ chorea chronica progressiva. Иньа въ виду, что chorea chronica progressiva ни разу не демонстрировалась въ Обще-

1) Додожено въ 0бществъ невропатодоговъ и психіатровъ при Казанскомъ Университеть въ огтабры 1910 г. 
ствћ невропатологовъ и психіатровъ и встрбчается довольно рћдо, я хочу воспользоваться әтимь случаемь въ гачествњ демонстраціи. Воть что дали анамнезъ и юлиническое наблюденіе:

Бољьной Т., 28 льтъ, крестьянинт новоуяенскаго у взда Самарской губерніи, поступиль въ клинику 25 сентября 1910 годә, съ жалобами ва постоянныя додергиванія и движевія во всбхъ частяхъ тьла. Изъ разспросовъ больного выдснилось, что его мать страдала такой же больввью, при чемь больвнь у матери началась незначительными подергиваніям въ возрасть 40 л过т и постепенно непровзвольныя движенія у нея усиливались, такъ что къ концу ея жизни судороги у нея были гораздо сильнье, ч安м у нашего больного. Всего

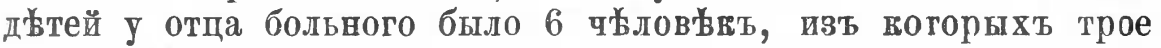
умерло въ дытскомь возрасть; причины ихт смерти больной не зваеть. Оставшіяся въ живыхь сестры вдоровы. Отецъ умеръ- причина его смерти больному невзвьстна. Самъ больной родился въ 1882 году; никаяих поврежденій при рожденіи не было. Въ цьтствь нивакой бользнью не страдаль, вообще рось здоровымъ. Учился въ сельской школь; ученье больному давалось легко. Половая зрьлость прошла безь бользвенныхъ явленіи; подовыя сношенія съ 15 льть, частыя. Имееть двухь дытей: сыну 5 льть, дочери 4 года, дыти здоровы. Въ теченіе посльвдихъ пяти лить больной алкоголя не ушотребляль; раньше пиль, хотя ве въ очень большомт голичеств. Курить много и съ малольтства. Половая способность сохранена. Сильныхъ потрясені въ жияни не помнить, вромь одного случая, когда бодьной испугался свиньи, поторая его хоть́⿻上丨 увусить во время освобожденія завязпаго въ воротахь поросенга. Травму, простуду, инфекціонныя забольванія, сифились и туберкулезь больной отрицаеть. Причпну настоящаго вабольванія указать не можеть, хотя связываетъ свою бользнь съ вышеупомянутымь пспугомь. Судороги у больного началась льть 6 тому назадъ и, по словамъ больного, съ верхнихъ юонечностей. Первое время әти подергвванія были очень слабы и заметны только самому больному, но постепенно эти подергиванія усиливались п перешли на все тйло, тақт что посльдвіе три года больной уже ве въ 
состояніп работать. Бользнь все время прогрессируеть и каґихъ-нибудь ремиссій въ теченій бользненнаго продесса не имется.

Status praesens. Пропзвольныя движевія глазъ въ пред有лахъ нормы. Автъ жевавія и глотанія не разстроенъ. Высунүть дзыкъ впередт не можеть, м шають нешроизвольныя движенія въ мыпцахъ языка. Произвольныя движенія головы, туловища, верхнихъ и вижнихъ конечностей по объему и си-

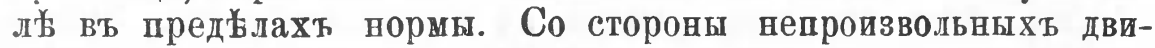
женій у нашего больного отмьчаются судорожныя двкжевія и подергиванія во всбхь частяхь тыла. Голова больного находится въ постоянвомь движеніи, ова то ваклоняется, то разгибается, то вращается въ разныя стороны; в'ъ то же время В'ь лицв больного можно видыть массу всевозможныхъ гримассь и ужимокъ; то овъ наморщить лобъ, то закроетъ одинъ глазъ, кақь бы подмигивая, то вытянеть впередъ губы, то обнаружит вубы, благодаря нешроизвольной обпирной улыбז6. Глазвые яблоки также участвують въ непропзвольныхь движеніяхъ. Ръчь больного отрывиста и не ясна. Руки больного находятся въ безпрерывномъ движевік; то заносить ихь на гопову, то закинеть ихъ ва спину, то сгибаеть ихъ в'ъ ловть, то разгибаеть, то провируеть, то супенируеть; זъ непроиявольнымь движеніямь присоединяются и пальды въ смысль сгибанія, разгибанія, отведенія и приведенія. Если больной сидить, то и туловище его принимаеть участіе въ непроизвольномъ движеніи: больной то наклонится впередъ, то назадъ или въ бокъ, то поворачввается винтообразно вогругъ продольвой оси түловища. Въ нижнихъ конечностяхъ также замьтны судороги; онъ выражаются движевіями отведенія и приведевія въ тазобедренномь суставъ, разгибанія и сгибанія ноги въ кольны и движеніями въ разныхъ направлевіяхъ въ голеностопномь суставь. Походва больного сильно разстроена и неправильна. Шаги больного не равномьрны, при чемъ больной качается изъ стороны въ сторону и часто увловяется то вправо, то вльво оть прямого направленія. Всявія волненія усшливають описанные выше непропзвольныя движепія, подт вліяніемъ же воли больного онь на нвкоторое время стихають и больному часто удается достигнуть намьченной дъли; такъ, онъ можеть 'ьсть, пользуясь ложвой, надыть чулокъ на ногу и т. и. Во время сна всь непроцзволь- 
ныя движеніл у нашего больного прекращаются совершевно. Сухожильные рефлексы на вернихт ковечностяхъ оживлены. Гольнные и ахилловы живые; клонуса стопы ныть. Подош венный, брюшной и на cremastor нормальнаго 'ипа. Зрачви равномьрны, съ живой реакдіей на свьть. Рефлексы: корнеальный коньюнктивальный, глоточный и сь мягкаго небы нормальвы. Авальный рефлексь сохраненъ. Функція тазовыхъ органовъ въ порядвь. Пассивныя движенія соверпенно свободны, вьть викакого вамека ва тугоподвижность. Зр'tвіе, вкуст п слухъ-нормальны. Со стороны глазного дна вьть викақихь измьненій. Обоняніе понижево всльдствіе закупорки носового отверстія засохшимися выдыленіями со слизистои оболочки носа. Всь виды чувствительности вь предылахъ вормы. Похудынія вонечностей не отм'учается. Питаніе мышечнаго скелета, пожныхъ покрововъ и костей удовлетворительно. Әлектровово́удимость мышцт и нервовт нормальна, Товы сердца чисты. Моча нормальна. Поягничный проколь, произведенный 6 октября 1910 года ассистевтомт клиники В. П. Первушинымь, даль сльдующіе результаты: давленіе черешно-мозговой жидвости нормально, лимфоцитозь 4, 3; реав ція Nonne положительна: имьется легкая муть.

Со сторовы психической сферы сльдуеть отмктить: узость кругозора; больной незваеть названія рьки, которая протекаеть черезь его село; недостаточное количество представле. вій п понятій: изь 12 мескдевь въ году можеть назвать тодько четыре: январь, февраль, сянтябрь, октябрь. Изь времень года внаеть тольво три, при чемь перечисляеть ихь вь сльдуюпемъ порядкь: зима, осень, льто. Дни недьли перечисляеть; сколько дней въ мбсяц не внаеть; недостаточное развитіе ассоціативныхъ процессовь и логичесвихъ операцій; задержка мыплевія; вапр., осевь помьпаеть посль зимы; 4 и 4 складываеть правильно, а 3 изь 8 отнять не можеть, даже если ему повазывають ва пальдахъ; слабость сужденія; хочеть поправиться, чтобы весело жить; настроеніе благодуш ное; незамьтно, чтобы тяготился своими умственными дефевтами; легво смьется, особенво, вогда отвьчаеть невпопадъ; вниманіе ослаблено.

21 октября с./г. въ 5 час. 25 мин. вечера было провзведено эвспериментально-психологическое изсль́дованіе психики T., по атласу првв.-дод. Рьбакова, врачемъ Л. Воскре. 
сенскимъ, работагпимт при каөедрь дүшевныхъ бользней. Цередъ изсльдованіемъ больной обыль въ нысколько угнетешномь состояніи, ночь и день провель нормально. Т. Зрительнья очуиенія. Способность къ различенію оттьнковъ цвбтовъ ионижена, опибки въ сторону большей интензивности. Коэффидіевть св бтовыхь ощущевій $=1,6$; Коэффидіенть спо собности къ различевію цв'ьтовъ $=0,6$. II. Bниманіе. Вниманіе вначительно разстроено. Показатель степени напряженности вниманія = 1 . Изсльдуемый ве могъ правильно сосчнтать 12 б'ылхъ кружковъ. Автивное вниманіе съ выборомъ ослаблево: не могъ сосчитать 46 черныхъ кружћов' въ теченіе 85 сећундъ. Показатель объема внимавія=2. III. Наблюдательноспь Наблюдательность понижена; погазанные рисунву: замокъ, топорт и клещи не могь указать при другомь расположеніи среди многихь рисунговъ. IV. Память. Память значительно ослаблена: не мог'ь повторить 4 обывновенных'ь слова въ опредьленномъ порядкь. Коэффидіенть запоминанія рисунковъ $=0,6$. V. Сужденіе. Способность сужденія и умозағлюченія представляють серьевныя уклоненія оть нормы: изсльдуемый не могъ объяснить картину, на которой изображено, кацъ мальчикъ, вздумавшій воровать яблоки, быль жестоко за это наказанъ садовникомъ. VI. Boсnрismie u запо. минаніе. Воспріятіе и запоминаніе в'ь звачительной мрй ослаблены: поқазанную въ теченіе 30 секундъ картину, изобра. жающую 2-хъ коров'ь, изт которыхъ одну доить женщина, могь ва словахъ передать такъ: „корова..... доять ее...... двъ бабы..."; при qемъ на это ушло 95 сегундъ.

Уже при одномъ взгдяд官 на больного первое, что обращаетъ ва себя напе внимавіе,-это непроизвольныя, неправильныя судороги въ области различныхъ мышцъ, а потому первый вопросъ, воторый приходится р'ьшать при поставовк'́ діагноза хронической прогрессивной хореи-это вопрось о томљ, имьются ли въ данномъ случањ дыйствительно хорешческія движенія иди другой какой-нибудь видъ судорогь, сходный по вньшнему виду съ хореическим. Въ этомъ отношеніи хроническую хорею легче всего см'шать сь той больвненной формоџ, которая носить назвавіe maladie de tic co- 
nvulsif вли myospadia impulsiva. Бользвь эта, какъ и chorea chronica progressiva,一неизльчима, насльдственна, развивается не остро, а медленно, и длится многіе годы, но несмотря ва әто сходство, между объими формами имеется и существенное различіе. При тикь непроизвольныя движенія больпею частью бываютъ въ одныхъ и т安хъ же мышечныхъ группахъ, отличаясь болье быстрымъ, такъ сказать, молніеобразнымт сокращеніемь мышц; вром' того, функція вонечностей почти не разстраивается; для myospadia impulsiva характерно повтореніе кавого-нибудь слова, васильственное проиянесеніе бранныхъ словъ и фразъ, явленіе, извьстное подъ названіемъ копролалік, также повтореніе видтнныхъ движевій (эхопраксія), подражаніе звукамь (әхолалія); ничего подобнаго у хо. репковь мы ве встрьчаемь. Можно бы привять подергиванія у нашего больного за судороги при chorea posthemiplegica, такъ вањ хореическія движенія при этой формь больвни пмьють хровическое теченіе, оставаясь на всю жизнь больного, но главнымь отличіемъ служить то обстоятельство, что судороги при chorea posthemiplegica бывають в'ь одной qасги тьла, при чемь изь анамнеза всегда выясняется, что судороги развились на пораженной половин安 тьла посл它 мозгового кровоизліянія или размягченія, а посему двустороннія судороги у нашего больного и отсутствіе мозгового инсульта въ анамнезъ, говорятъ за хроничесвую хорею, Отсутствіе тугоподвижности и харэктернаго ритмическаго tremor'a висти и пальцевъ, а тажже отсутствіе застывшаго, маскообразнаго выраженія лица, исключають вт данномь случаб дрожжательный параличь. Не сльдуеть упускать изь вида и истерію, проявлюпуюся въ хореиформныхъ судорогахъ; но не имъя въ данномъ случаб̆ ви одного изъ симптомов', свойствевных' истеріп, какъ то: быстрой смъны настроевій, черезмърно-развитого воображенія, различныхъ разстройствь чувствительности, судорожныхъ, объемистыхт, сложныхъ движеній въ руæахъ, ногахъ и головњ, двшженій, қоторыя повторяются одно- 
образно, съ большой правильностью, ритмически, и не видя въ теченіе самой бользви никавихъ қолебаній въ проявленіях' бользни, мы имьемъ полное основаніе исключить здысь истерію. Но особенно дегко можно впасть въ ошибку, принявъ за хровическую хорею обыкновенную chorea minor. Однимъ изъ отличительныхъ пршзнаковъ chorea chronica propressiva отъ chorea minor является насльдственность, при qемъ вабольваніе хроничесвой хореей въ молодыхь годахъ особевво часто наблюдается при семейной форм' страдавія, при которой каждое сльдующее покольніе обыкновенно поражается все въ болье и болъе раннемъ возрасть. Обращаясь вт исторіи бользни нашего больного, мы видимъ, что онъ забольль въ болье раннемь возрасть (22 хъ льть), чьмъ его мать (ва 40 -мъ году). Другимь тавимъ же важвымь отдичительнымъ признакомъ хронической хореи отъ chorea minor, носящей всъ признаки остраго ивфекціоннаго забольванія, являегся хроническое прогрессирующее теченіе больвни у напего больного, по большей части безъ ремиссій въ теченіе бользвеннаго шроцесса; говоря „по большей части“, я имью въ виду то обстоятельство, что ремшссіи могутъ, хотя и ръдко, наступать и при хронической хоређ, какъ объ әтомъ сообщаеть Schulze. Изъ авамнеза больного мы видимъ, что бользнь его въ теченіе 6-ти ль'ь все прогрессируетъ, а по амо́улаторнымъ дандымъ клиници, жоторую больной впервые пос'ьтил въ 1908 году, мы имемь основаніе заключить, что въ теченіи его больвни не иметея наваких ремиссій, а нацротивь, бользн его все болье и болье усиливается. Далье, мы знаемъ, что хореическія движенія при хронической прогрессивной хоpé, подчиневы произвольнымт движеніямь, и нашь больной самъ ъстъ, пользуясь дожвой, можеть самъ надыть ва ногу чулокъ и т. д. Навовецъ, въ пользу хровической хореи говорить и очень сильное изиненіе психики нашего больного.

Для полноты обзора остановлюсь еще на двухъ формахъ мозгового забольванія, воторыя при сочеганіи психическихт 
и нервныхъ симптомовъ могуть подать поводъ къ см'шшенію еъ хровической хореей. Эти формы: общій прогрессивный параличъ помьшанныхъ и разсъянный склерозь. Прежде всего анамнезь напего больного указываеть на одвородную насльдственность; далъе, на первый плань у нашего больного выступаеть забывqпвость, благодупное настроевіе, тогда какь при вачаль бользви у паралитиковъ эвфорическій стадій со. провождается мавіакальнымъ возбужденіемь съ повышенной предпріимqивостью и большею аффективностью. Кромь того, прогрессивный параличт начинается разстройствомь психивъ, тогда какь у хореиковъ бользнь обыквовенно начинается двигательнымъ разстройствомь. По клинической каргины судороги паралитивовъ-это клоническія судороги съ распредыленіемъ в'ь порядкь корковыхь центровљ, у нашего больного имбются безпорядочныя, разнообразныя, размапистыя движенія. Отличіе заплючается и вт теченіи бользви: прогрессивный параличъ начинается острбе, течеть скачками, даеть ухудшенія и улучшенія; хровическая прогрессивная хорея натего больного началась медленво, прогрессивво увеличиваясь безъ колебаній въ ту шли другую сторону. Отличіе раз-

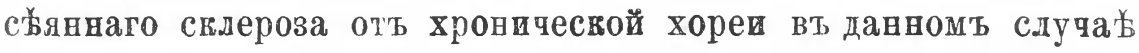
не представляеть затрудвеній; нйть у больного нистагма, очень qастаго при разсьяннов склерозь; судороги при равсьянномь склерозь носять характерь дрожанія, усиливающагося при произвольномь движевів; размапистыхъ и какь бы цұллесообразныхъ двпљевій хореиковъ у склеротиковь ве ваблюдается, ватьм's у склеротиновт обычны спазмы и гипертовіи, при прогрессивной хоређ, если и бывають параличи, то слабые. Теченіе разсьяннаго склерова скачками, сь звачительньми ремиссіями, при прогрессивной хронической хореь теqевіе бользни цавинообразное, прогрессивное, съ ухудпевіем. Съ психическй стороны при хореб уже въ началь' замбтны разстройство памяти и слабоуміе, при разсћянномб склероз占 разстройство памяти выступаеть въ поздньйшее вре- 
мл, а на первомъ планъ каргина пспхоза сказывается легкой депрессіей и раздражительностью.

Тавимъ образомъ медлевно прогрессирующее теqеніе бо. льзни у нашего больвого, разлитыя, не ритмическія, хореическія судороги, нормальная чувствительность, отсутствіе тугоподвияности при живыхъ рефлексахъ, иям'ьненіе психивп и однородная васл安дствевность дають мнъ полное основаніе поставитьь здысь діагнозъ chorea chronica progressiva.

Что касается этіологичесваго момента у нашего больного, то главная роль выпадаеть на долю насльдственности, которая при описываемой бользви представляетъ собою такое обычное явлевіе, что Huntington и другіе авторы хроническую хорею прямо отождествляля сь хореей насльдствевной. Насльдственность при хронической хореъ большей qастью бываетъ прямой и передается отъ отца къ сыну, въ вашемъ случағ оть матери въ сыну, отъ сына к' внуку च т. Д. Сплошь и рядомъ chorea chronica является бользнью фамильной, но не подлежить сомяннію тоть фавть, что в'ь правтићв встрьчаются и такіе случаи, гды самое тщательное изученіе генеалогіи больного не даеть намъ права говорить ви о прямой насльдственности ни объ особыхъ предрасположеніяхъ къ забольванію нервной састемы. Что же касается ближайшихь причинъ возникновенія бользни, то въ литературь пм'юются Јказанія ва травму, ревматизмь, эндокардить, а такле на душевное волненіе, какъ таповой момевтъ, всльды за которым'ь наступило развитіе ошисываемой бользвей. И для нашего больного, быть можегъ, шри его насльдственности достаточво и того испуга, о которомъ мы упомянуди въ авамвезљ, чтобы ва сдену выстушила характерная картина хронической хореи.

Что васается измьненій со стороны нервной сдстемы при хронической хореъ, то при мавроскопическомь осмотрб нервной системы лица, умершаго при явлевіяхъ хровичесвой щрогрессивной хореу, въ нывоторыхъ случаяхъ не отврывает- 
ся ничего венормальнаго, въ нькоторыхъ же случаяхъ уле грубое обсльдованіе невооруженнымъ глазомъ обнаруживаеть со стороны мозга пьлый рядъ грубо-анатомическихъ взмъневій. Такъ, обычнымъ явленіемъ при chorea chronica можно считать картину розлитого деребрадьнаго пахимевингита, лептоминингита, замьтное упломеніе мовговыхъ извиливъ, общую атрофію головного мозга и пр. Что касается микроскопическихъ измыненій нервной системы, то они открываются, главвымъ обравомь, въ предыллах головного мозга, но отчасти въ области мозжечка и въ области спинного мозга. Въ головномъ мозгу измьневія вонстатируются по преимуществу въ корь двигательной области и въ подлежащемъ бьломь веществ. Здысь можво видыть ясно выраженную мелковльточную ивфильтрацію, при чемь ивфильтрирующіе әлементы иногда бывагть разсъяны равномьрно по всей гор屯 и суо́кортика.льомь бъломъ веществь, иногда особенно обильно скапливаются въ перицеллюлярныхъ пространствахъ гавгліозных' ћльток' и при томъ в'ь тьхь отдылахъ, гды располагаются малыя и средвія парамиды, при чемь въ малыхь и среднихъ пирамидахъ модно констатировать или сравнительно нцчтожныя измененія или же рьзкую деструкцію ихъ, какъ то: хромотолизъ кльточнаго тьла, распадъ ввутриклйточныхъ волоконъ, перемьщеніе ядра, измьневія ядрышка; Бетцевскія же кынти обынно сохраняють свой нормалны видъ. Рядомъ съ пораженіемъ гангліозныхъ кльтовъ мозговой коры нерьдқо, имьеть нсто убыль тангенціальныхъ волоқонъ и волоконъ str. superradialis. Kровевосные сосуды тақже могуть претерпьвать рядъ иямћненій, чаще всего констатируется рьзкое утолценіе адвентиціи. Въ предълахъ мозжечка можно қонстатировать ть же самыя измйненія, какія мы встрбчаемъ въ головномъ мозгу. Въ сдинномъ мозгу очень часто ве удается отқрыть ничего ненормальнаго, хотя въ литературь есть увазанія на пораженія вльтов переднихъ ро- 
говъ, перерожденіе заднихъ юорешковъ и на отдъльныя моста поражевія периферической части боговыхъ столбовъ.

Такимь образомь въ настоящее время хроническая прогрессивая хорея относится къ разряду органическихъ страдаві: нервной системы. Данныя поясничнаго прокола у нашего больного дають мнь ньькоторое основаніе думать, что у него имьется органическое забольваніе, такъ вакъ лимфоцитозъ у больного равняется 4,3 , близкій въ патологическому, а главвое, реапція Nonne дала положительный результать-очевь слабая муть.

Всю суть страдавія при хронической хорећ авторы усматривают'ь не въ грубоанатомических' ввм'веніяхъ, находимыхъ со стороны дантральной нервной системы, а въ измьвеніях' микроскопическихъ, отьрываемыхъ въ области коры большого мозга. Возвращаясь вт нашему случаю, мы всь главньйшіе элементы кливической картины страданіл больного безъ труда можемь объяснить ловализаціей бользненнаго процесса въ корь двигательной области головного мозга. Наличность двигательныхъ разстройствъ въ формь хореическихь судорогъ у нашего больного мы можемъ связать съ пораженіемъ малыхъ и среднихъ пирамидъ мозговой

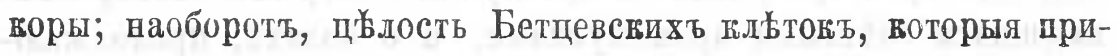
знаютея за начало воловонь пирамидныхь путей объясняють намь, почему нашт больной можеть подавлять свои судороги собственной волей. Ненорядки же въ сферь интеллекта нашего хоревка съ полвым правомь могуть быть отнесевы ва сqеть убыли тангендіальныхь волоконъ и волоконъ str. superradialis, но если мы еще примемь во внимавіе, qто болььненный продессь захватываеть лобныя доли, то вамь уже совсьмъ понятно измыненіе психики у нашего больного. 